\section{Noise Exposure Levels in Black Tea Processing Factories and Its Effects on Employees}

Siyah Çay Üretim Tesislerinde Gürültü Maruziyet Düzeyleri ve Çalışanlar Üzerindeki Etkileri

\section{Gryasettin ÇIÇEK $^{1 *}$, Sarp Korkut SÜMER ${ }^{2}$}

\begin{abstract}
The aim of this study was to determine the daily noise exposure levels in black tea processing factories and to evaluate its effects on employees' occupational health and safety. In the study, the sound pressure level dBA values were measured at the ear levels of the employees in each production unit in three tea factories operating in Artvin Province. These factories where the measurements were made consist of withering, curling, oxidation, drying (boiler and stove) and classification units. These units include various systems and mechanisms formed by conveyors, fans, steam heaters, boilers, reducers, pallets, hoods, screens, gears, and drums. In the measurements performed considering the ISO 9612:2009 (Acoustics Determination of Occupational Noise Exposure Engineering Method) standard, a sound pressure level meter in Type-2 class complying with the requirements of the IEC 616721: 2002 was used. A weighted equivalent sound pressure levels were determined using the measured values. Considering these values and working times, personal daily noise exposure levels were calculated. It was determined that the equivalent sound pressure levels and daily personal noise exposure levels at the employee ear level were in the range of 77-87 dBA and 74-83 dBA, respectively. Curling units have the highest equivalent sound pressure level $(86.81 \mathrm{dBA})$ and daily personal noise exposure level value ( $83.10 \mathrm{dBA})$ compared to other units, while boilers have the lowest equivalent sound pressure level $(76.75 \mathrm{dBA})$ and daily personal noise exposure level value $(73.55 \mathrm{dBA})$. Considering the regulation on protection of employees from noise related risks, it was concluded that the daily noise exposure level reached the lower exposure action value $(80 \mathrm{dBA})$ in these factories. The study showed that the health and work efficiency of the employees could be adversely affected by noise in tea factories, considering various research results and Regulations on noise.
\end{abstract}

Keywords: Tea processing, Noise measurement, Sound pressure level, Occupational health, Ergonomics

\footnotetext{
1*Sorumlu Yazar/Corresponding Author: Giyasettin ÇiÇEK, Çanakkale Onsekiz Mart Üniversitesi Zir. Fak. Tarım Mak. ve Tekn. Müh. Böl., Çanakkale, Türkiye. E-mail: giyas@comu.edu.tr (D) OrcID: 0000-0001-8260-1667

${ }^{2}$ Sarp Korkut SÜMER, Çanakkale Onsekiz Mart Üniversitesi Zir. Fak. Tarım Mak. ve Tekn. Müh. Böl., Çanakkale, Türkiye. E-mail: $\underline{\text { sarksumer@comu.edu.tr }}$ (iD OrcID: 0000-0001-7679-6154

Atıf/Citation: Çiçek, G., Sümer, S.K. Noise Exposure Levels in Black Tea Processing Factories and Its Effects on Employees. Tekirda ̌̆ Ziraat Fakültesi Dergisi, 18 (2), 282-291.

(CBu çalışma Tekirdağ Namık Kemal Üniversitesi tarafından Creative Commons Lisansı (https://creativecommons.org/licenses/by-nc/4.0/) kapsamında yayınlanmıştır. Tekirdağ 2020
} 


\section{Özet}

Bu çalışmanın amacı, siyah çay fabrikalarındaki günlük gürültü maruziyet düzeylerini belirlemek ve çalışanların iş sağlığı ve güvenliği üzerindeki etkilerini değerlendirmektir. Çalışmada Artvin ilinde faaliyet gösteren üç çay fabrikasının her bir üretim biriminde çalışanların kulak seviyelerinde ses basınç düzeyi dBA değerleri ölçülmüştür. Ölçümlerin yapıldığı bu fabrikalar soldurma, kıvırma, oksidasyon, kurutma (kazan ve soba) ve sınıflandırma birimlerinden oluşmaktadır. Bu üniteler; konveyörler, fanlar, buharlı ısıtıcılar, kazanlar, redüktörler, paletler, davlumbazlar, elekler, dişliler ve tamburlardan oluşan çeşitli sistem ve mekanizmaları içermektedir. ISO 9612: 2009 (Mesleki Gürültü Maruziyet Mühendisliği Yöntemi) standardı dikkate alınarak yapılan ölçümlerde IEC 61672-1: 2002 şartlarına uygun Tip-2 sınıfında bir ses basınç düzeyi ölçer kullanılmıştır. Ölçülen değerler kullanılarak A ağılıklı eşdeğer ses basıncı seviyeleri belirlenmiştir. Bu değerler ve çalışma süreleri dikkate alınarak kişisel günlük gürültü maruziyet seviyeleri hesaplanmıştır. Çalışanların kulak seviyesindeki eşdeğer ses basınç seviyeleri ve günlük kișisel gürültü maruziyet seviyelerinin sırasıyla 77-87 dBA ve 74-83 dBA aralığında olduğu belirlenmiştir. Ölçüm yapılan tüm üniteler içerisinde, kıvırma ünitelerinin diğer ünitelere kıyasla en yüksek eşdeğer ses basınç seviyesine ( $86.81 \mathrm{dBA}$ ) ve günlük kişisel gürültü maruziyet seviyesine ( $83.10 \mathrm{dBA})$ sahipken, kazanların en düşük eşdeğer ses basınç seviyesine (76.75 dBA) ve günlük kişisel gürültü maruziyet seviyesi değerine (73.55 dBA) sahip olduğu tespit edilmiştir. Çalışanların gürültüye bağlı risklerden korunmasına ilişkin yönetmelik dikkate alındığında, bu fabrikalarda günlük gürültü maruziyet seviyesinin en düşük günlük kişisel gürültü maruziyet eylem değerine $(80 \mathrm{dBA})$ ulaştığı sonucuna varılmıştır. Çalışmada elde edilen veriler, çeşitli araştırma sonuçları ve gürültü yönetmeliği dikkate alındığında, çalışanların iş sağlığı ve güvenliğinin yanı sıra iş verimliliğinin çay fabrikalarındaki gürültüden olumsuz etkilenebileceğini göstermiştir.

Anahtar Kelimeler: Çay üretimi, Gürültü ölçümü, Ses basınç düzeyi, İş sağlığı, Ergonomi 


\section{Introduction}

Tea is the most frequently consumed drink worldwide, next to water, and about $75 \%$ of the total world tea production includes black tea (Saptashish and Jolvis, 2016). Tea production is carried out in 45 countries in the tropics and subtropical climate zones. Countries with the greatest tea cultivation area in the world are China, India, Sri Lanka, Kenya, Indonesia, Vietnam, and Turkey. Turkey located 197 tea factories, seventh in terms of the width of tea cultivation area (76 thousand hectares) ranks fifth in dry tea production (243 thousand tons) (FAO 2016). In dry tea processing, wet tea leaf goes through withering, curling, oxidation, drying (boiler and stove) and classification processes. Although the machines used in these processes provide advantages such as reducing workload and decreasing dependence on people, they can also cause some negative working conditions (Crocker, 2007). One of the risk factors causing these conditions is noise. Noise can have negative effects on employee health in terms of physical, physiological, psychological and performance (Sabancı and Sümer, 2015; Erdoğan ve Yazgan, 2007). The effects of noise in indoor studies have attracted the attention of many researchers and studies have been carried out to determine noise levels and their effects on people in factories.

Yağmur (2016) conducted a study on the evaluation of the vibration and noise exposures of workers in flour production and put forward some protective and preventive suggestions. In a study conducted by Gönüllü et al. (2002), the sources that cause noise according to the types of processes at the different indoor industries were defined and the equivalent sound pressure levels $\left(\mathrm{L}_{\mathrm{eq}}\right)$ were determined. Konuklar (2016) carried out a study to determine the noise exposures of workers in weaving factories. Daily personal noise exposure levels of the employees were determined with the task-based measurement strategy. Ege et al. (2003) carried out a study on determining noise levels and evaluating their effects in textile factories. Ateş and Alagöz (2018) measured sound pressure levels $(\mathrm{dBA})$ in a factory manufacturing agricultural machinery and evaluated their effects on workers according to the relevant regulations. Özgüven (2012) determined the noise levels of some units (mixer, selector and hammer feed crushing machine) used for post-harvest operations indoor and created noise maps.

In this study, task-defined noise level measurements were made by considering noise sources in tea factories, daily noise exposure levels of employees were determined according to TS EN ISO 9612 standards, and the results were evaluated, taking into account the varying activities within the factory. The current regulations and working conditions were considered in the noise measurements made at the ear level of the employees and in the evaluation of the results.

\section{Material and Method}

The study was carried out in three tea factories (F1, F2 and F3) in Artvin province. In the factories where the measurements are made, all units were the same in terms of working principle. These factories consist of withering, curling, oxidation, drying (boiler and stove) and classification units. In order to determine the measurement strategy in the study, all factors (work, production, process, organization, employees, working time) that can contribute to noise exposure were analyzed. When the daily noise exposure is composed of two or more periods of noise exposure of different levels, their combined effect should be considered, rather than the individual effect of each (OSHA, 2020). As a result of the analysis done with this approach, it was determined that the task-based measurement strategy was suitable for the study and measurements were performed. According to the task-based measurement strategy, all tasks performed by the employees within a working day were defined, the working time of each task was determined precisely, and sound pressure level measurements were made for each task separately.

In the measurements, a SPL meter in Type-2 class complying with the requirements of IEC 61672-1: 2002 was used. (TESTO 816-1). Calibration of sound level meter was performed by using Testo Schall IEC 60942 Class 2 calibrator complying with the of IEC 61672-1: 2002, which defines the SPL as 94 and $114 \mathrm{dBA}$. The measurements of A weighted SPL (dBA) for all sub-tasks of the operators in each unit were conducted for about 5 min with three replications at the ear levels of operators (ISO 9612:2009).

The measurements were performed by recording data every second and 300 values were obtained in each repetition. Equivalent SPL (LAeq) values were calculated by Equation (1) using the obtained SPLs dBA. Durations (Tm) for each task were determined by observing operators' occupational activities in tea factories and interviewing them. 


$$
L_{p, A e q T, m}=10 \log \left[\frac{1}{I} \sum_{i=1}^{I} 10^{0,1 x L_{p, A, e q T, m i}}\right]
$$

where;

$$
\begin{array}{ll}
L_{p, A e q T, m i}: \text { LAeq for task } \mathrm{m}, \mathrm{dBA} \\
\mathrm{i} & : \text { Task sample number } \\
\mathrm{I} & : \text { Total number of task samples } \\
\mathrm{m} & : \text { Task number }
\end{array}
$$

Equation (2) was used to calculate the relative contribution of each task to the daily personal noise exposure levels of operators according to the task-based measurement strategy specified in the EN ISO 9612 standard, using the $\mathrm{L}_{\text {Aeq }}$ values determined by Equation (1) and effective duration of each task in the working day.

$$
L_{E X, 8 h, m}=L_{p, A e q T, m}+10 \log \left[\frac{\bar{T}_{m}}{T_{0}}\right]
$$

Where;

$L_{E X, 8 h, m} \quad:$ LAeq for task m contributing to the daily noise exposure level, $\mathrm{dB}(\mathrm{A})$

$\bar{T}_{m} \quad:$ Effective duration of the working day for task $\mathrm{m}, \mathrm{h}$

$T_{0} \quad:$ Reference duration, $8 \mathrm{~h}$

Daily personal noise exposure levels were calculated with Equation (3).

$$
L_{E X, 8 h}=10 \log \left[\sum_{m=1}^{M} \frac{\bar{T}_{m}}{T_{0}} 10^{0,1 x L_{p, A, e q T, m}}\right]
$$

Where;

$L_{E X, 8 \mathrm{~h}} \quad$ : Daily noise exposure level normalized to nominal $8 \mathrm{~h}$ working day, dBA

$\mathrm{M}$

: Total number of tasks

In the study, factory and production unit-based comparisons and evaluations were made considering the noise parameters measured and calculated. The parameters were summarized with charts and graphs, including standard deviation values. The possible effects of daily noise exposure values on operators were evaluated and discussed by considering Directive 2003/10/EC of the European Parliament and of the Council (minimum health and safety requirements regarding the exposure of workers to the risks arising from physical agents).

\section{Results and Discussion}

In the present study, it was determined that the equivalent continuous sound pressure level (Leq) in factories ranged from 79.65 to $84.48 \mathrm{dBA}$ and the daily exposure level (LEX) ranged from 75.73 to $79.45 \mathrm{dBA}$. When the $\mathrm{L}_{\mathrm{eq}}, \mathrm{L}_{\max }$ and $\mathrm{L}_{\mathrm{EX}}$ values determined for three factories are examined, it is seen that the values between factories are close (Table 1). Considering the averages of each unit for three factories, it was determined that the Leq values in the units of factories varied between $76.75 \mathrm{dBA}$ and $86.81 \mathrm{dBA}$, and the LEx values varied between $73.55 \mathrm{dBA}$ and $83.10 \mathrm{dBA}$ (Table 2).

Curling units have the highest $\mathrm{L}_{\text {eq }}(86.81 \mathrm{dBA})$ and LEX value (83.10 dBA) compared to other units, while boilers have the lowest $\mathrm{L}_{\mathrm{eq}}(76.75 \mathrm{dBA})$ and $\mathrm{L}_{\mathrm{Ex}}$ value $(73.55 \mathrm{dBA})$. In the curling units, cleaning process is carried out with compressed air for duration of 1 hour at randomized times. During the cleaning process, an average of $98.42 \mathrm{~dB}$ (A) Leq and $94.62 \mathrm{~dB}$ (A) Lex values were determined. These values can be explained as the most important reason for the high noise parameters in the curling unit. Employees of the boiler unit spend most of their time in the boiler room, and in case of necessity, they leave to control the boiler. Therefore, the noise parameters determined for the boiler unit were found to be the lowest (Table 1, Figure 1). 
Table 1. $L_{e q}, L_{\max }$ and $L_{E X}$ values of units at the 3 factories

Tablo 1. Fabrikalarda ünitelere ait $L_{\text {eq }}, L_{\max }$ ve $L_{E X}$ değerleri

\begin{tabular}{|c|c|c|c|c|c|c|c|c|c|}
\hline \multicolumn{10}{|c|}{ Noise parameters of the factories, $\mathrm{dBA}$} \\
\hline Units & & F1 & & & $\mathrm{F} 2$ & & & F3 & \\
\hline & $\mathrm{L}_{\mathrm{eq}}$ & $\mathrm{L}_{\max }$ & $\overline{L_{E X}}$ & $\mathrm{~L}_{\mathrm{eq}}$ & $\mathrm{L}_{\max }$ & $\overline{L_{E X}}$ & $\mathrm{~L}_{\mathrm{eq}}$ & $\mathrm{L}_{\max }$ & $\overline{L_{E X}}$ \\
\hline Unloading & $80.92 \pm 0.37$ & $99.70 \pm 6.36$ & $73.53 \pm 0.37$ & $84.88 \pm 0.31$ & $95.50 \pm 3.50$ & $79.37 \pm 0.31$ & $81.12 \pm 6.34$ & $89.97 \pm 1.86$ & $74.63 \pm 6.34$ \\
\hline Withering & $70.00 \pm 0.98$ & $86.17 \pm 5.06$ & $67.59 \pm 0.98$ & $87.83 \pm 6.56$ & $94.20 \pm 3.48$ & $82.39 \pm 6.56$ & $78.17 \pm 0.57$ & $86.50 \pm 4.20$ & $71.40 \pm 0.57$ \\
\hline Curling & $84.70 \pm 2.09$ & $91.47 \pm 1.05$ & $86.57 \pm 2.09$ & $89.44 \pm 0.45$ & $95.47 \pm 1.90$ & $83.68 \pm 0.45$ & $86.28 \pm 0.32$ & $93.03 \pm 3.44$ & $79.06 \pm 0.32$ \\
\hline Oxidation & $82.36 \pm 0.17$ & $89.40 \pm 0.26$ & $77.05 \pm 0.17$ & $81.37 \pm 2.94$ & $90.03 \pm 4.63$ & $76.66 \pm 2.94$ & $84.11 \pm 0.35$ & $90.27 \pm 0.32$ & $79.16 \pm 0.35$ \\
\hline Boiler & $79.23 \pm 3.99$ & $92.57 \pm 3.06$ & $75.98 \pm 3.99$ & $78.04 \pm 2.72$ & $93.10 \pm 3.47$ & $74.82 \pm 2.72$ & $72.98 \pm 3.11$ & $95.57 \pm 1.30$ & $69.85 \pm 3.11$ \\
\hline Oven & $82.81 \pm 0.22$ & $89.63 \pm 1.77$ & $77.49 \pm 0.22$ & $85.43 \pm 0.90$ & $93.27 \pm 2.76$ & $80.04 \pm 0.90$ & $84.32 \pm 1.64$ & $91.77 \pm 1.37$ & $77.56 \pm 1.64$ \\
\hline Classification & $77.51 \pm 1.21$ & $92.03 \pm 3.07$ & $71.94 \pm 1.21$ & $84.40 \pm 1.13$ & $91.23 \pm 1.00$ & $79.17 \pm 1.13$ & $79.37 \pm 0.91$ & $86.63 \pm 3.31$ & $73.03 \pm 0.91$ \\
\hline Averaged & $79.65 \pm 1.29$ & $91.57 \pm 2.95$ & $75.73 \pm 1.29$ & $84.48 \pm 2.14$ & $93.26 \pm 2.96$ & $79.45 \pm 2.14$ & $80.91 \pm 1.89$ & $90.39 \pm 2.26$ & $74.96 \pm 1.89$ \\
\hline
\end{tabular}

Table 2. Averaged $L_{e q}, L_{E X}$ and $L_{\max }$ levels of factories in production units, $d B A$

Tablo 2. Ünitelerin ortalama $L_{e q}$, Lmax ve $L_{E X}$ değerleri

\begin{tabular}{lccc}
\hline Units & $\mathrm{L}_{\mathrm{eq}}$ & $\mathrm{L}_{\mathrm{EX}}$ & $\mathrm{L}_{\max }$ \\
\hline Unloading & $82.31 \pm 2.34$ & $75.84 \pm 3.10$ & $94.72 \pm 5.41$ \\
Withering & $78.67 \pm 2.70$ & $73.80 \pm 7.69$ & $88.96 \pm 4.54$ \\
Curling & $86.81 \pm 0.95$ & $83.10 \pm 3.79$ & $92.51 \pm 0.90$ \\
Oxidation & $82.61 \pm 1.15$ & $77.62 \pm 1.35$ & $89.90 \pm 0.45$ \\
Boiler & $76.75 \pm 3.27$ & $73.55 \pm 3.26$ & $93.74 \pm 1.60$ \\
Oven & $84.19 \pm 0.92$ & $78.36 \pm 1.45$ & $91.56 \pm 1.83$ \\
Classification & $80.43 \pm 1.08$ & $74.71 \pm 3.90$ & $91.38 \pm 4.45$ \\
\hline
\end{tabular}

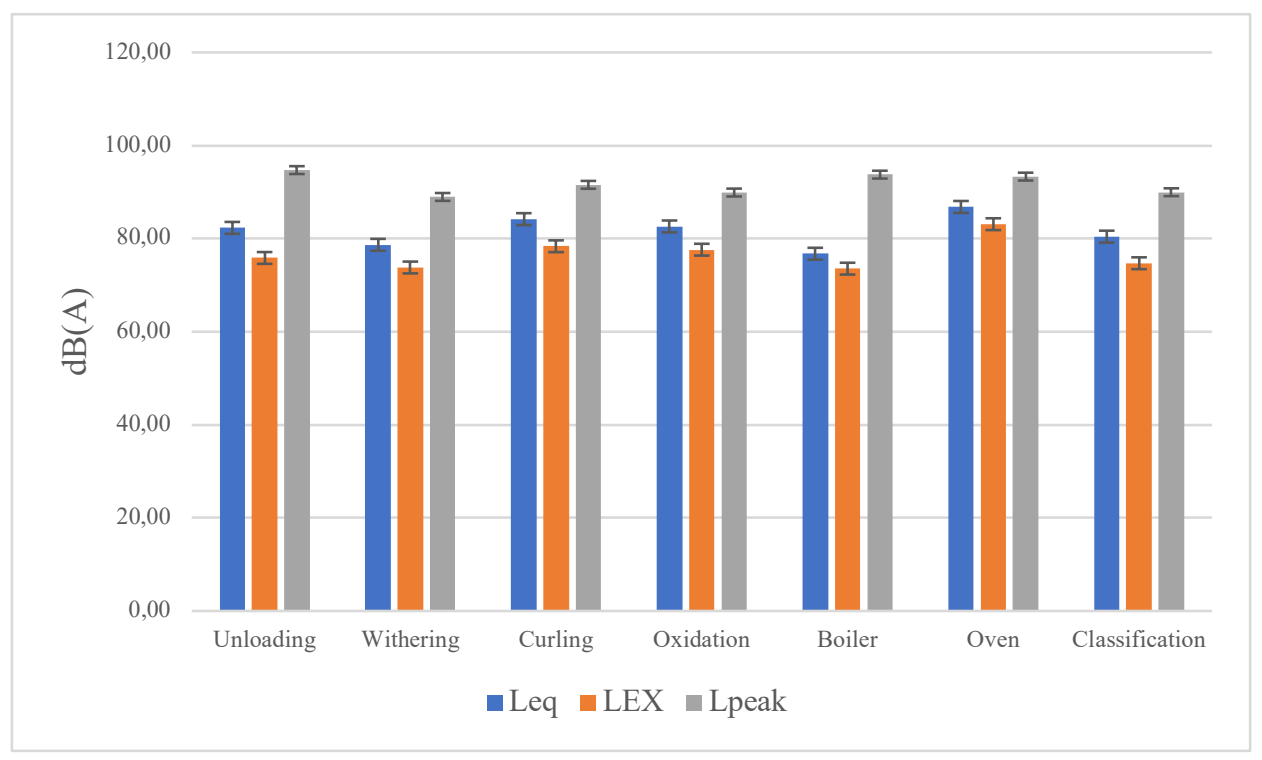

Şekil 1. Fabrikalarin ortalama $L_{\max }, L_{e q}$ ve $L_{E X}$ seviyeleri

Figure 1. Averaged $L_{m a x}, L_{e q}$ and $L_{E x}$ levels of the factories

$L_{\max }$, Leq and Lex parameters are generally determined in the studies conducted on the assessment of noise levels in the workplace and evaluations are made considering these values. Considering $L_{\max }$ values in evaluating the effects of noise on people at workplace will not give realistic results. This value, which expresses the highest (peak) SPLs among the values recorded during the measurement period, may vary depending on various external factors (people's shouting, phone conversation, hammer drop, etc.). Even the equivalent SPLs are not sufficient to evaluate the effects of noise. In order to evaluate the effects of ambient noise on workers, daily personal noise exposure levels (Lex) calculated using the equivalent SPL and durations exposed should be considered. The maximum noise level to which employees are permitted to be exposed within a working day (exposure action 
values) specified in the noise regulations refers to the daily personal noise exposure value (Lex). In other words, the noise exposure limits have been determined considering the LEX values. When the literature is examined, it is possible to come across many studies in which the effects of noise on persons are evaluated only by determining $\mathrm{L}_{\text {eq }}$ and $\mathrm{L}_{\max }$ values. In some of these studies, the equivalent SPLs determined have been incorrectly compared with the noise exposure limits specified in the regulations. This approach is like comparing apples and pears. In order to assess whether the employees work in accordance with the noise regulations, it is necessary to determine the daily personal noise exposure levels of the employees. Thanks to this approach, the effects of measured ambient noise on employees can be evaluated more accurately and adequate noise control measures can be effectively taken. In tea factories, operators have 1 to 3 hours breaks within a working day. Approximately 0.5 hour of this period is used for eating, and the rest is used for resting, toilet, smoking and similar needs (Table 3).

Table 3. Working and resting durations of employees, hour

Tablo 3. Ünitelerde ortalama çalışma, dinlenme ve yemek süreleri, saat

\begin{tabular}{lccc}
\hline & Working time & Resting & Lunch \\
\hline Unloading & 4.67 & 2.83 & 0.5 \\
Withering & 5.67 & 1.83 & 0.5 \\
Curling & 5 & 2.5 & 0.5 \\
Oxidation & 5.83 & 1.67 & 0.5 \\
Boiler & 7.5 & - & 0.5 \\
Oven & 6 & 1.5 & 0.5 \\
Classification & 5.67 & 1.83 & 0.5 \\
\hline Averaged & 5.76 & 1.74 & 0.5 \\
\hline
\end{tabular}

The $\mathrm{L}_{\mathrm{eq}}$ values determined in the dining halls of the F1, F2 and F3 coded factories are $68.86 \mathrm{dBA}, 83.28 \mathrm{dBA}$ ve $69.23 \mathrm{dBA}$, respectively. The fact that the resting areas are close to the working environments and that the employees cause noise in the resting areas (talking loudly, listening to television loudly, not closing the door, etc.) may cause changes on these values. A short duration spent in a less noisy ambiance can significantly reduce the employee's personal daily noise exposure level. For example, at the oven unit of F1 coded factory, the Leq value was determined as $82.81 \mathrm{dBA}$, however the Lex value of the operator, who had a 2-hour break, was calculated as $77.49 \mathrm{dBA}$.

The noise, which is one of the most important detrimental factors affecting the employees' carelessness, tiredness, and working capacity, should be reduced to safety limits (Sümer et al., 2006). Therefore, the noise control measures are of great importance in a workplace to protect the health of employees. The best way to reduce noise is to completely enclose its source, which is called "engineering control" (Kroemer, 2017). Another way of effective engineering control to reduce the noise exposure is isolating the operator from the noise source using an acoustically designed cab or barrier (Sümer et al., 2006). "Management controls" is another effective way to reduce noise exposure, such as regulating duration and frequency of breaks and limiting worker exposure (Harris, 1991). The last way, which is an alternative to reduce the noise exposure, is the use of personal protective equipment (PPE). This way is also called "temporary measure". The two basic types of hearing protection are the earmuffs and earplugs. These PPEs can reduce the sound levels by 15-30 dBA. Earmuffs usually provide better hearing protection than earplugs. Earplugs are also effective, but they may become irritating inside the ear and often are not inserted correctly, making them ineffective (Wilkinson, 2002). It was observed that none of the tea factories examined had any noise control to reduce noise.

Noise will continue to adversely affect human health, in physiological, physical and psychological context, unless necessary precautions are taken. Many acoustic studies report that different noise levels have an impact on employees, such as cognition, decision making, learning, calculation and hand-eye coordination (Sabanc1 and Sümer, 2015; Thatcher and Yeow, 2018). Thus, the noise has negative effects on the employees in terms of occupational health and safety, and it can also decrease the productivity of employees.

In the hearing loss classification of WHO (World Health Organization); it has been reported that prolonged exposure at 41-60 dB intervals causes hearing loss, $61-80 \mathrm{~dB}$ intervals can cause severe hearing loss. Additionally, it has been emphasized in the report that people working with loud machinery in industry or road construction must use PPE. Moreover, many acoustic studies reported that the noise will continue to adversely affect human 
health not only physically, but also in a physiological and psychological context, unless necessary precautions are taken. Serin and Akay (2008) stated that noise exposures in the range of 66-85 dBA have disturbing psychological effects in addition to hearing loss. In another study, Sakarya (2016) reported that exposures between 65-90 dBA caused physiological reactions on workers such as increase in blood pressure, increase in heart rate and breathing, decreased pressure in brain fluid. Noise exposure has also been identified as a risk factor for cardiovascular disease (Basner et al., 2014). In humans, several studies have shown that the noise causes mainly blood pressure elevation, changes in heartbeat and irregularities in breathing (Von Grandjean 1959; Andren et al., 1980). Toprak and Aktürk (2004) stated that noise reduces work efficiency for white-collar and blue-collar workers by $60 \%$ and $30 \%$, respectively. Grandjean (1988) informed that the reductions in working performance began in 50-60 dBs according to laboratory studies. Noisy workplaces can inhibit speech communication, mask warning signals, reduce mental performance, induce nausea, headaches, and tinnitus (ringing in the ears), cause temporary or permanent deafness (Corlett and Clark, 2009). Exposure to noise can also lead to annoyance and stress, which can affect the mental wellbeing of workers and the general population. Studies of occupational stress have found that that noise exposure can be a contributor to worker stress and annoyance depending on the type of work being performed (Melamed et al., 1997; Leather et al., 2003).

As can be seen, the effects of noise on employees' health and work efficiency have been revealed by various studies. However, regulations regarding the limitations of noise in the workplace have been done considering the physical effects on people. This effect has been emphasized in most scientific studies conducted.

There are many regulations that specify the permissible noise levels in the workplace. Noise in the workplace in Europe is regulated by the EU Directive 2003/10/EC, and in the United States by OSHA (Occupational Safety and Health Administration) 29 CFR (Code of Federal Regulations) 1910.95 Hearing Conservation Standard. There are also countries with stricter national regulations than those specified in EU and OSHA. According to EU regulations, the noise exposure should not exceed the exposure limit ( $87 \mathrm{dBA})$ during the length of a working day ( 8 hours) to protect employees from suffering deafness. Employers are required to take certain steps to reduce the harmful effects of noise on hearing. There are two main action levels that guide these steps: lower exposure action value (LEX, 8h) $80 \mathrm{dBA}$, upper exposure action value (LEX, 8h) $85 \mathrm{dBA}$. The lower exposure action value is a daily or weekly average noise exposure level of $80 \mathrm{dBA}$, at which the employer has to provide information and training and make hearing protection available. The upper exposure action value is set at a daily or weekly average noise exposure of $85 \mathrm{dBA}$, above which the employer is required to take reasonably practicable measures to reduce noise exposure, such as engineering controls or other technical measures. The use of PPE is also mandatory if the noise cannot be controlled by these measures (European Parliament and of the Council, 2003).

According to the results of the present study, employees work at noisy conditions below the lower exposure action value (daily, 8 hours) in all units except the curling unit at the factories. The effects of noise on employees vary not only depending on SPL but also on the duration of exposure (Sabanc1 et al., 2012). It has been determined that tea factories have the potential to adversely affect operators' health and work efficiency, as the works is performed at long exposure times and high SPLs. In a study conducted by Yildizlar (2018) in a tea production plant, it was reported that the measured equivalent SPL ( $\mathrm{L}_{\text {eq }}$ ) values ranged between 80 and $92 \mathrm{dBA}$, and $66 \%$ of 512 employees suffered hearing loss. However, in this study, the $\mathrm{L}_{\mathrm{EX}}$ values required for evaluations in consideration of the regulations were not determined. In the present study, while the equivalent SPLs indoor areas of factories ranged from 70 to $89 \mathrm{dBA}$. When considered the Leq values reported by Y1ldizlar (2018), it is seen that all employees face a similar risk in the tea factories evaluated.

In the present study, besides the noise in tea factories, it has been observed that the precautions taken for employees' health and safety are almost nonexistent. In addition, the awareness of employees regarding occupational health and safety is quite low and they are uneducated in this regard. So, it can be considered as they have performed the works, with very low risk perception.

\section{Conclusion}

It was concluded that the health and work efficiency of the employees were adversely affected at the production activities in the tea factories, considering various research results and EU Regulations on noise. The duration and 
conditions of the breaks in the daily activities of the employees had an impact on the LEX values. The directives on noise control state that employers are responsible for applying engineering and management controls of noise to minimize risks and providing employees with PPE if the upper daily noise exposure action level is exceeded. In the tea factories evaluated, these measures have not been taken, and therefore it is likely that hearing loss will occur in employees. Moreover, physiological, and psychological effects may cause serious disturbances. Along with the effects of noise on human health, effects such as preventing speech and masking warning signals will not only decrease the work efficiency of employees but also increase the risk of accidents. The implementation of engineering controls in tea factories is not easy, and sometimes impossible, considering the functions of machinery and the continuity of production. However, the applicability of management controls is high, such as providing a lunchroom isolated from noise and encouraging employees to eat at this area. In addition, apart from lunch break, periodic breaks can be arranged in areas with lower SPLs. As for the use of PPE, officials in the factories stated that the communication of employees with each other was important for process and malfunction checks, and that PPE use could prevent production continuity by reducing intercommunication and ability to hear sounds associated with malfunction. The use of Earmuffs with Microphones could be a good option to reduce noise exposures of employees and improve the communication between them.

\section{Acknowledgment}

This paper was prepared by using the project data supported by The Scientific Research Projects Coordination Unit (Project no: FHD-2019-2897) of Canakkale Onsekiz Mart University. 


\section{References}

Andren, L., Hansson, L., Björkman, M. and Jonsson, A. (1980). Noise as a contributing factor in the development of elevated arterial pressure. Acta Medico Scandinavica, 207, 493-498.

Ateş, E. and Alagöz, M., (2018). Noise Analysis at a Company manufacturing agricultural machinery (in Turkish). Karaelmas Journal of Occupational Health and Safety. 2(1), 13-22.

Basner, M., Babisch, W., Davis, A., Brink, M. and Clark, C., (2014). Auditory and non-auditory effects of noise on health. Lancet, p.13251332.

Corlett, E.N. and Clark, T.S., (2009). The ergonomics of workspaces and machines, A design manual Second Edition, Taylor \& Francis eLibrary, ISBN 0-203-48261-1 (e-book), pp:163.

Crocker, M.J., (2007). General introduction to Noise and Vibration Effects on People and Hearing Conservation in Handbook of Noise and Vibration Control, pp.303-307, Eds Crocker, M.J., John Wiley \& Sons, NewYork.

Directive 2003/10/EC of the European parliament and of the council of 6 February 2003 on the minimum health and safety requirements regarding the exposure of workers to the risks arising from physical agents (noise). https://eur-lex.europa.eu/legalcontent/en/ALL/?uri=CELEX\%3A32003L0010 accessed 15.03.2020.

Ege, F., Sümer S.K. and Sabanc1, A., (2003). Noise level in textile plant and its effects (in Turkish). Turkish Medical Association Occupational Health and Safety Journal. 30-39.

Erdoğan, E. and Yazgan, M.E., (2007). Landscaping to reduce traffic noise problem in cities: Ankara case. Journal of Tekirdag Agricultural Faculty. 4 (2), 201-210.

FAO, (2016). Food and Agricultural Organization of the United Nations. http://www.fao.org/faostat/

Gönüllü, M.T., Avşar, Y., Arslankaya, E. and Tosun, I., (2002). Investigation of noise occurring in different industrial units and evaluation of hearing health (in Turkish), IV.GAP Engineering Congress Proceedings, Şanlıurfa, 1390-1395.

Grandjean, E., (1988). Fitting the Task to the Man A Textbook of occupational ergonomics. Taylor \& Francis Ltd, London.

Harris, D., (1991). Noise control manual guidelines for problem-solving in the industrial/commercial acoustical environment. the Noise Control Association (NCA), Springer Science+Business Media New York, ISBN 978-1-4757-6009-5 (e-Book)

Konuklar, B., (2016). Noise exposures of employees in weaving plants (in Turkish). Occupational Health and Safety Specialization Thesis, Ministry of Labor and Social Security, General Directorate of Occupational Health and Safety, Ankara, pp: 98.

Kroemer, K.H.E., (2017). Fitting the human introduction to ergonomics-human factors engineering. Seventh edition. CRC Press Taylor \& Francis Group. Book Number-13: 978-1-498 -4689-2 (Hardback).

Leather, P., Beale, D. and Sullivan, L., (2003). Noise, psychosocial stress and their interaction in the workplace. J. Environ. Psychol., 23(2), $213-222$.

Melamed, S., Froom, P., Kristal-Boneh, E., Gofer, D. and Ribak, J., (1997). Industrial noise exposure, noise annoyance, and serum lipid levels in blue-collar workers. Arch. Environ. Health, 52(4), 292-298.

OSHA, (2020). Occupational safety and health administration. Regulations (Standards-29 CFR) Occupational noise exposure. - 1910.95 , 1998.

Özgüven, M., (2012). Investigation of noise maps for some post-harvest agricultural machinery used indoor spaces (in Turkish). Journal of Tekirdag Agricultural Faculty. 9 (3), 45-53.

Sabancı, A. and Sümer, S.K., (2015). Ergonomics (in Turkish). Nobel Academic Publishing, Ankara. ISBN:978-605-5426-79-8. Second edition. pp:472.

Sabanc1, A. and Sümer, S.K., Say, S.M., (2012). Industrial ergonomics (in Turkish). Nobel Academic Publishing, Ankara ISBN: 978-605-133329-8. pp:261.

Sakarya E. (2016). Working life and the effects of noise noise analysis study of a construction site in (in Turkish). University of Üsküdar. MSc. Thesis, 2016.

Saptashish D. and Jolvis Pou K.E. (2016). A Review of Withering in the Processing of Black Tea. J. of Biosystems Eng. 41(4):365-372. https://doi.org/10.5307/JBE.2016.41.4.365.

Serin H., and Akay A.E., (2008). Analysis of the noise level as a result of logging (in Turkish). 14. National Ergonomics Congres, Trabzon, $412-416$.

Sümer, S.K., Say, S.M., Ege, F. and Sabanc1, A., (2006). Noise exposed of the operators of combine harvesters with and without a cab. J. Appl. Ergon. (37), 749-756.

Thatcher, A. and Yeow, P.H.P., (2018). Ergonomics and human factors for a sustainable future, current research and future possibilities. Part of Springer Nature. ISBN 978-981-10-8071-5 ISBN 978-981-10-8072-2 
Toprak, R. and Aktürk, N., (2004). The negative effects of noise on human health. The Turkish Bulletin of Hygiene and Experimental Biology, 61(1), 49-58.

TS EN ISO 9612: (2009). Türk Standardı, Akustik-Çalışma Ortamında Maruz Kalınan Gürültünün Belirlenmesi-Mühendislik Yöntemi.

Von Grandjean, E., (1959). The effects of noise on vegetative and endocrine functions (in German). Journal of Preventive Medicine, (4), 3-40.

WHO, (1991). Report of the informal working group on prevention of deafness and hearing impairment programme planning, Geneva, 18-21 June 1991. Retrieved March 16, 2020.

Wilkinson, R., (2002). Avoiding hearing losses on the farm. Michigan State University Extension, National Institute of Occupational Safety and Health https://nasdonline.org/220/d000019/avoiding-hearing-losses-on-the-farm.html accessed 17.02.2020.

Yağmur, R., (2016). Evaluation of occupational noise and vibration exposure at flour production (in Turkish) Ministry of Labour and Social Security, Directorate General of Occupational Health and Safety Thesis for Occupational Health and Safety Expertise Ankara, 2016, Ankara. pp:81.

Yıldızlar, H.Y., (2018). Investigation of noise, vibration thermal comfort parameters in A TEA factory. MSc. Thesis. Avrasya University Institute of Health Sciences, Trabzon, pp:67. 